\title{
HOPLITIS ANTHOCOPOIDES, A EUROPEAN MASON BEE ESTABLISHED IN NEW YORK STATE (HYMENOPTERA: MEGACHILIDAE)
}

\author{
By George C. Eickwort ${ }^{1}$
}

Hoplitis anthocopoides (Schenck) (new combination for Osmia anthocopoides Schenck, I853) was discovered in Albany County, New York State, in the summer of 1969 . (Fig. I). This bee is a common inhabitant of Central Europe and is found as far north as Scandinavia and as far south as Greece. In Europe, the bee is usually known as Osmia spinolae Schenck (e.g., Dalla Torre, I 896; Friese, 1926) or as Osmia caementaria Gerstaecker (e.g., Schmiedeknecht, 1884-85; Friese, 1923; Blüthgen, 1930). However, spinolae, the oldest name for the species, is preoccupied in Osmia, and the name caementaria is younger than anthocopoides, which has been rarely used in recent literature (e.g., Hedicke, 1930). Most European authors do not recognize Hoplitis as a separate genus and place anthocopoides and its relatives in Osmia.

Hoplitis anthocopoides is similar to $H$. adunca (Panzer), the type species of Hoplitis Klug and its synonym, Ctenosmia Thomsen. The species is thus a member of the nominate subgenus, which previously was restricted to the Old World. The subgenus (as Ctenosmia) was briefly described by Schmiedeknecht (1884-85).

\section{Description}

New York specimens fit the species descriptions of Gerstaecker (1869), Schmiedeknecht (1884-85), and Blüthgen (1930), and have been compared with European specimens by Dr. E. Stanek and are conspecific. The following notes, emphasizing the characters used by Michener (1947) to describe the American subgenera of Hoplitis, will distinguish $H$. anthocopoides from other American Hoplitis:

Female: Length 8.5-10.5 mm. Integument black. Pubescence generally white; scopa yellowish-white; metasomal (gastral) terga I -5 with narrow white apical hair bands, often interrupted medially. In fresh specimens, dorsal pubescence light ochraceous. Head and thorax distinctly and closely punctate, punctures usually separated by less than their diameter. Clypeus (Fig. 2) strongly convex,

\footnotetext{
${ }^{1}$ Department of Entomology and Limnology, Cornell University, Ithaca, New York 14850.
} 


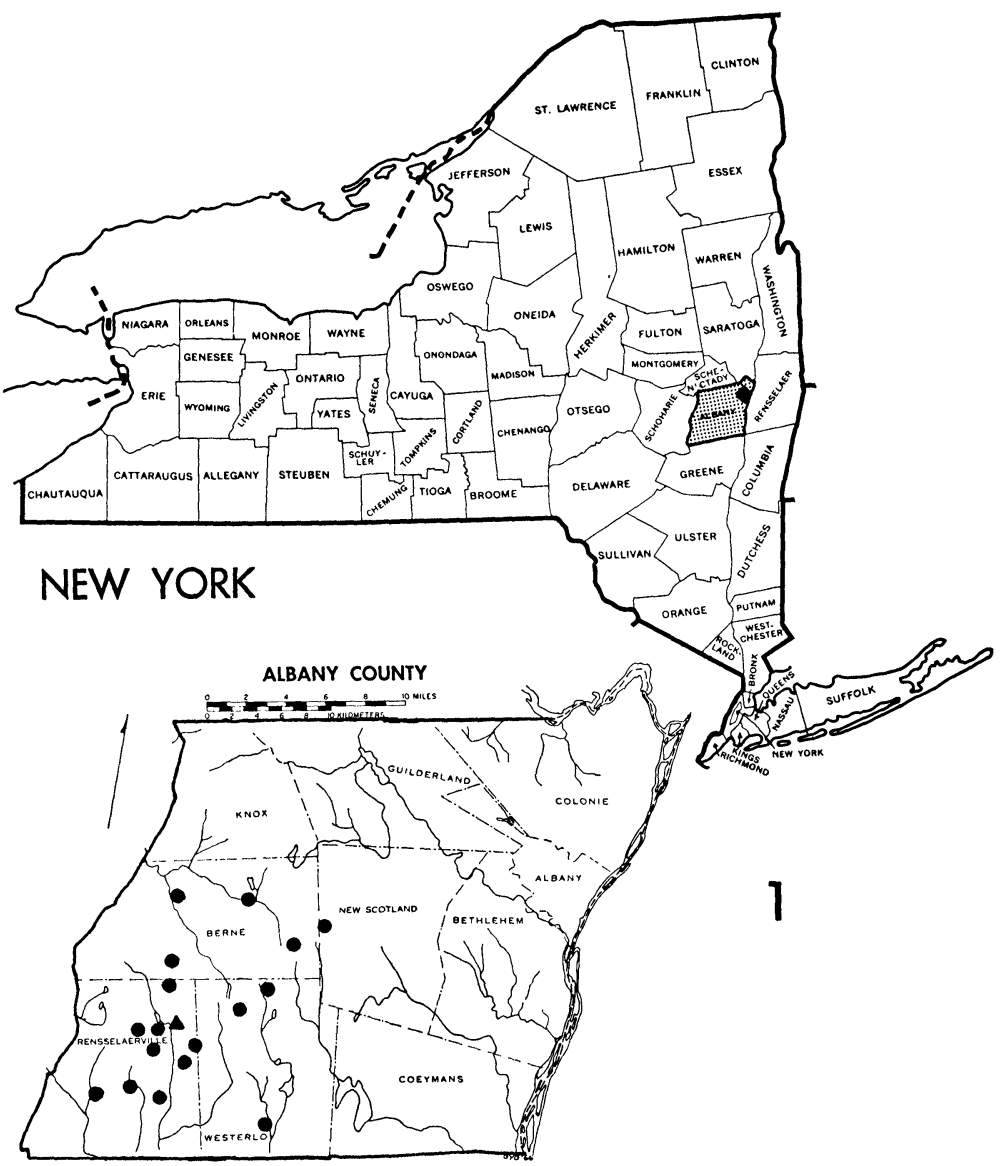

Fig. 1. Range of Hoplitis anthocopoides in New York State in 1969. Albany County shaded in state map, enlarged below. Circles, peripheral and important central collections of $H$. anthocopoides; triangle, Rensselaerville; diamond on state map, City of Albany. 
closely and distinctly punctate to apex, apical margin truncate, crenulate, and only slightly projecting over base of labrum. Inner margins of eyes slightly convergent below; genae subequal in width to eyes in lateral view. Mandibles (Fig. 4) tridentate, long, narrowed medially. Mouthparts long; length of galea subequal to width of head; second segment of labial palp 1.5-1.7 times length of segment I ; third segment of maxillary palp longest, fifth segment slender. Antennae with flagellar segment I much longer than pedicel and subequal in length to segments 2 plus 3 . Thorax robust, metanotum on posterior surface so that anterior part is lower than convexity of scutellum. Wings papillate distally. Metasoma (gaster) rather broad, length from dorsal margin of anterior concavity of first tergum I.O-I.3 times maximum width, punctures not distinct; terga I-5 without impunctate margins. Anterior surface of tergum I shallowly concave, impunctate, with longitudinal sulcus, sharply delimited from dorsal surface. Last visible (sixth) tergum concave in lateral view, impunctate rim slightly raised and shining; last visible (sixth) sternum unmodified.

Male: Length 8.0-10.0 mm. Pubescence long, white in older specimens, in young specimens dorsally and laterally more orange than in females. Clypeus with long hairs. Mandibles (Fig. 5) bidentate. Antennal scape (excluding basal bulb) 2.6-2.7 times longer than broad; pedicel mostly exposed; first flagellar segment I.35-I.45 times as long as segment 2; flagellomeres flattened but segments not otherwise modified; terminal flagellomere rounded (Fig. 3). Posterior coxae unmodified. Metasomal tergum 6 laterally toothed, apical margin irregularly sinuate medially; tergum 7 projected to rounded truncate apex, with small teeth laterally (Fig. 6). Metasomal sterna 2-5 with low, transverse, submarginal swellings and without median projections; sternum 6 (Fig. 7) with bilobed median apical projection bearing dense patches of erect setae; sterna 7 and 8 as in Figures 8 and 9. External genitalia as in Figures ro and II.

Position among the American subgenera of Hoplitis

Michener (1947) has revised the American subgenera and species of Hoplitis. In an account of the megachiline bees of California, Hurd and Michener ( I955) revised Michener's key to the American subgenera, synonymizing 2 subgenera and including 2 taxa previously considered to be separate genera. In a numerical study of the American species in the Hoplitis complex of genera, Michener and 


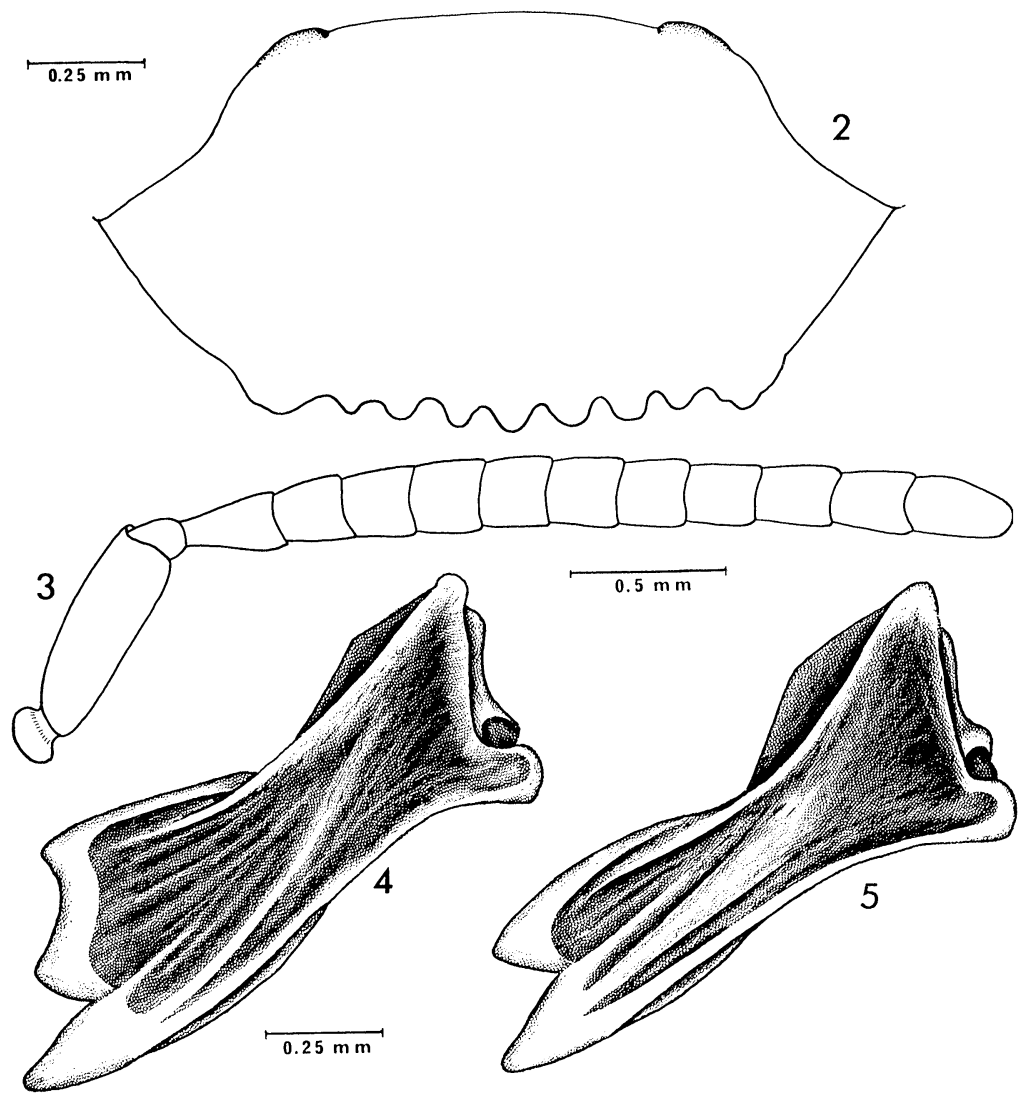

Figs. 2-5. Hoplitis anthocopoides. 2, clypeus of female; 3, antenna of male; 4-5, left mandibles, lateral view (4, female; 5 , male).

Sokal (1957) removed 2 subgenera, Hoplitina and Acrosmia, from Hoplitis and placed them in the genus Proteriades. Michener (1968) has recently synonymized Anthocopa s.l. with Hoplitis s.l. If the subgenera of Anthocopa are now to be considered as subgenera of Hoplitis, there are currently I I subgenera of native Hoplitis: Andronicus, Monumetha, Dasyosmia, Cyrtosmia, Alcidamea, Formicapis, Robertsonella, Atoposmia, Hexosmia, Eremosmia, and Isosmia. The Old World Hoplitis are more abundant and diverse than their American counterparts, and the genus is probably of Old World 


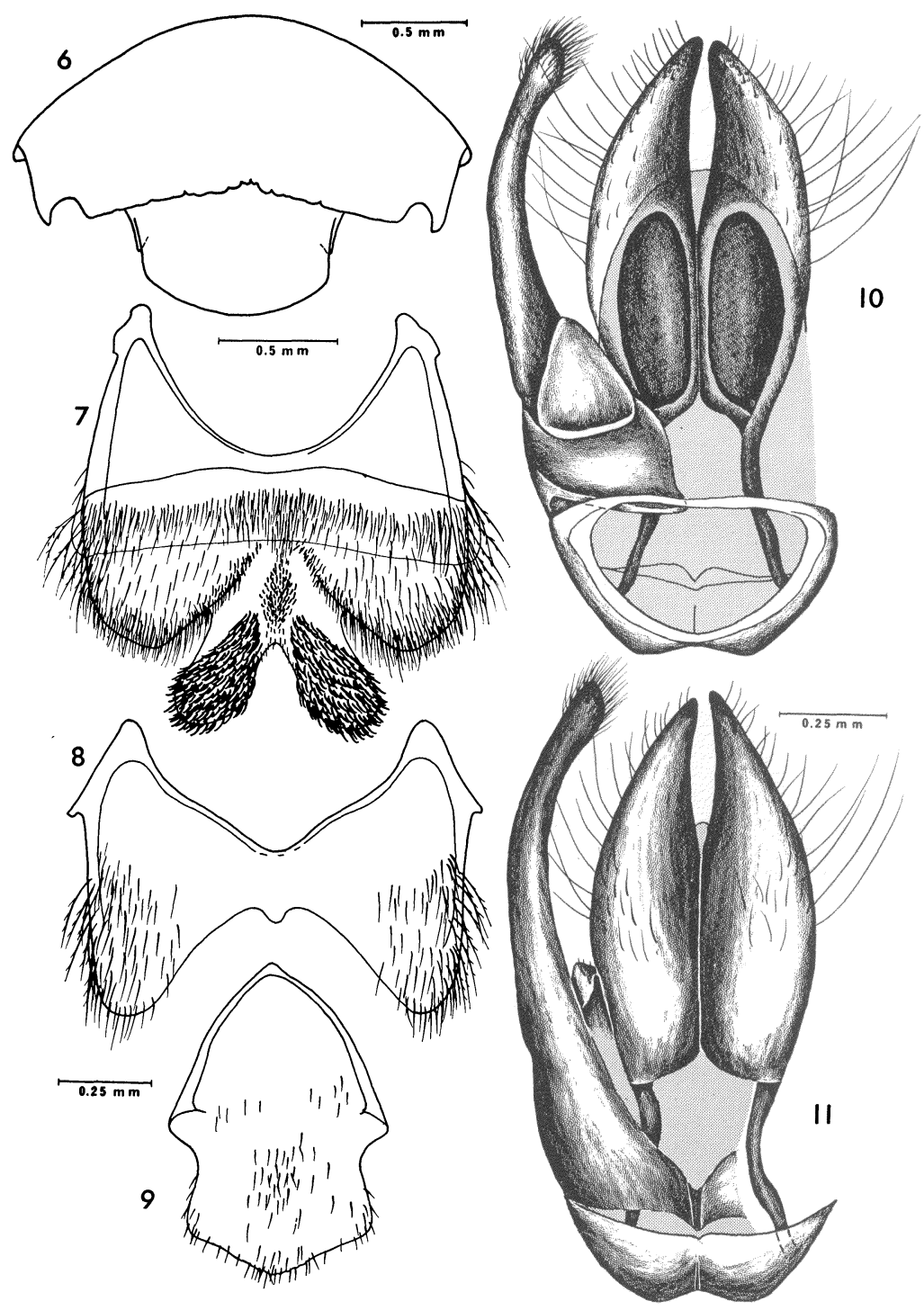

Figs. 6-11. Metasomal structures of male Hoplitis anthocopoides. 6, terga 6 and $7 ; 7$, sternum $6 ; 8$, sternum $7 ; 9$, sternum $8 ; 10-11$, external genitalia (10, ventral view; 11 , dorsal view). 
origin (Michener, 1947). However, only one native American subgenus, Alcidamea, also contains Old World species. The genus is absent in the Neotropical region south of Mexico.

The above subgenera (except Isosmia, which was described as a subgenus of Anthocopa by Michener and Sokal, 1957) can be distinguished by means of the subgeneric keys to Anthocopa and Hoplitis in Hurd and Michener (1955). Hoplitis (Hoplitis), based on anthocopoides, runs to couplet 8 of Hurd and Michener's key to Hoplitis based on males, if the second alternative of couplet 6 is changed to read:

Seventh tergum produced to a pointed or truncate apex; antennae modified; scape often thickened, the flagellum flattened and the last segment often pointed; clypeus with the usual long hairs 7

The remainder of the key should be changed as follows:

8(7) Antennal pedicel almost completely hidden in concavity at end of scape when antennae are in normal position; last antennal segment bent and drawn out to a point Alcidamea

Antennal pedicel at least partly exposed; last antennal segment rounded, or if pointed as in Alcidamea, posterior coxae each with broad ventral tooth

9(8) Seventh metasomal tergum produced to median point or tridentate; posterior coxae each with broad ventral tooth; Western

Dasyosmia

Seventh metasomal tergum produced to subtruncate apex (Fig. 6) ; posterior coxae unmodified; Northeastern Hoplitis s.s.

In Hurd and Michener's (1955) key to subgenera of Hoplitis based on females, Hoplitis s.s. runs to couplet 7. The remainder of the key, excluding Acrosmia (now in Proteriades), can be changed as follows:

7(5) Mandibles short and broad, not narrowed medially and apices much narrower than eye; first flagellar segment of antennae subequal to pedicel Alcidamea

Mandibles longer and narrowed medially (Fig. 4) or apices nearly as broad as eye; first flagellar segment longer than pedicel

8(7) Clypeal margin not crenulate, impunctate; apices of mandibles nearly as broad as eye; Western

Dasyosmia

Clypeal margin crenulate (Fig. 2), punctate to apex; apices of mandibles much narrower than eye; Northeastern .... Hoplitis s.s. 
Position among New York species of Hoplitis

Mitchell (1962) lists 6 native species of Hoplitis that are known from or might be expected to occur in New York State. Most are less robust and smaller than $H$. anthocopoides; only $H$. cylindrica (Cresson) and H. truncata (Cresson) typically overlap it in size. In Mitchell's key to the species of Hoplitis based on females, the second alternative of couplet 4 should lead to (Hoplitis s.s.) as well as to (Alcidamea), and should direct the user to $6 \mathrm{a}$.

Couplet 6 a may be inserted to follow 6 as follows:

6a(4) Apical margin of clypeus crenulate (Fig. 2); first flagellar segment of antennae subequal to 2 plus 3 ; mandibles long, narrowed medially (Fig. 4). (Hoplitis s.s.) anthocopoides Schenck Apical margin of clypeus not crenulate; first flagellar segment of antennae shorter than 2 plus 3 ; mandibles short and broad, not narrowed medially (Alcidamea)

In Mitchell's key to the males, couplet 4 should be modified as follows:

4(2) Small (8 $\mathrm{mm}$ or less); antennae filiform, median segments narrow and elongate; abdominal tergum 7 simple, broadly rounded (Robertsonella)

Larger ( $8 \mathrm{~mm}$ or more); antennae modified, median segments not much longer than broad; abdominal tergum 7 produced to pointed or truncate apex

Hoplitis anthocopoides then runs to couplet 8, which should be changed as follows:

8. Clypeus with appressed tomentum; margins of abdominal sterna $I$ and 2 with slender median spines

(Monumetha) albifrons Kirby

Clypeus with long erect pubescence; margins of abdominal sterna $I$ and 2 without spines

9. Apical segment of antennae curved, tapering to a point; pedicel nearly concealed by scape (Alcidamea) truncata Cresson Apical segment of antennae straight, rounded; pedicel largely exposed (Fig. 3) (Hoplitis s.s.) anthocopoides Schenck

Distribution and Biology

In Europe, Hoplitis anthocopoides collects pollen exclusively from 2 species of blue-flowered Boraginaceae, Echium vulgare Linnaeus 
and occasionally Anchusa officinalis Linnaeus. Both plants have been introduced into eastern North America, where Echium, known as viper's bugloss or blueweed, has become a common weed on disturbed sites with poor rocky or sandy soil. In the area southwest of Albany, New York, Echium is found principally along roadsides, on gravel beds along streams, in slate quarries, and in overgrazed pastures. I observed that the female bees collect pollen only from Echium vulgare (Anchusa was not found there); moreover, both sexes visit only Echium for nectar.

This oligotrophy allowed us to accurately plot the range of $H$. anthocopoides by examining roadside stands of Echium, whose distinctive appearance can be easily recognized from a slowly moving automobile. Peripheral and important central collections of the bee are indicated by circles on the Albany County map in Figure I. All of these sites are on the Helderberg Plateau, an extension of the Catskill Mountains largely covered by second-growth woodlands and pastures. The bee is most abundant to the southwest of Rensselaerville (center of operations for this study, indicated by a triangle in Fig. I), where extensive rocky pastures provide both nest sites and abundant Echium. To the north, the Helderberg Plateau drops precipitously to the Mohawk River valley, where Echium is almost completely absent. To the south, the plateau descends more gradually to the Catskill Creek valley, where Echium is also scarce. Hoplitis anthocopoides was represented by few specimens in most peripheral collecting sites, sometimes only by a single male, despite intensive searching. The bee was not found in patches of Echium beyond the indicated range and was also consistently absent from some patches within its range boundaries. The extent of the range towards the Hudson River in the east, and especially towards Schoharie County in the west, may not be accurate since I was not able to cruise many roads in those areas before the end of the bee's flight season. $^{2}$ However, a collecting trip through Schoharie County to Otsego County during flight season produced no $H$. anthocopoides at apparently suitable stands of Echium.

In Europe, $H$. anthocopoides is well known for the mortar-andpebble nests it builds on the surfaces of boulders (see especially Gerstaecker, I869; Torka, I913; Friese, 1923; and Jøker, 1942).

\footnotetext{
${ }^{2}$ Note added in proof: In $1970 \mathrm{H}$. anthocopoides was found throughout most of Albany County, east to the Hudson River, and west 10 miles into Schoharie County. This range extension probably represents previously established populations in areas not searched in 1969.
} 
These nests are constructed very similarly to those of the famous European mason bees of the genus Chalicodoma, and I propose that we also use the vernacular name "mason bee" to refer to $H$. anthocopoides and related Hoplitis (Hoplitis) with similar habits. My study of its nesting behavior in New York will be presented in a future paper.

None of the native American Hoplitis whose biologies have been investigated are mason bees. All but one species build rows of cells, one above the other, in tubular holes in dead stems or tree trunks (reviewed by Michener, 1947, and Hurd and Michener, 1955). The one exception, H. (Dasyosmia) biscutellae (Cockerell), has been recorded as nesting in soil by Linsley and MacSwain (1943) and reusing mud-dauber (Sceliphron) nests by Stephen, Bohart, and Torchio (1969). However, some American Osmia build exposed nests on rock surfaces (Stephen, Bohart, and Torchio, I969), including at least one species at Rensselaerville.

Freshly emerged males and females of $H$. anthocopoides were first seen on June I4. Adults are common to the latter part of July, when they taper off, and are rare after August I. The last adult was seen on August I9.

\section{Discussion}

Megachilid bees have frequently been transported long distances by man, probably because their nests are often concealed in the stems and crevices of plants and other articles of commerce. In the United States, 5 Old World species other than the mason bee have been intruduced in historical times (Mitchell, I962; Jaycox, 1967). Megachile rotundata (Fabricius) and $M$. concinna Smith are now both widespread in this country, and the former species has been semi-domesticated for alfalfa seed production in the Pacific Northwest. Megachile concinna presumably reached this country from the West Indies after World War II, and had probably reached the West Indies from Africa in the early igth century. Megachile apicalis Spinola has been recorded several times from eastern North America but may not be established. Chalicodoma lanata (Fabricius) was apparently introduced into the West Indies with the slave trade, and has recently been found in southern Florida. The most recent introduction has taken place around Ithaca, New York, about 120 miles from the range of $H$. anthocopoides, where the European Anthidium manicatum (Linnaeus) was first collected in I963 (Jaycox, I967). This species is common in the Ithaca area and 
is extending its range (L. Pechuman, personal communication). In addition, 4 other North American megachilid bees, Osmia coerulescens (Linnaeus), O. inermis (Zetterstedt), O. nigriventris (Zetterstedt), and Megachile centuncularis (Linnaeus), also occur in the Old World (Mitchell, 1962), and may have been accidentally introduced by man before records were kept.

All of the introduced megachilids except the mason bee are polylectic, although they show preferences for certain flowers and frequently visit plants of European origin (Hurd, 1954; Stephen and Torchio, 1961; Pechuman, 1967). Hoplitis anthocopoides is the first oligolectic bee of any family to accidentally follow its host plant to the United States. The host is a widespread and common weed and the nest sites are abundant and rarely used by native bees. There is little doubt that $H$. anthocopoides will extend its range over much of eastern North America. Since even vanguard mason bees can be easily detected on roadside stands of viper's bugloss, its range extension can be followed more exactly than that of any other introduced species. I urge entomologists in the Northeast to be on the watch for the mason bee.

\section{Summary}

Hoplitis (Hoplitis) anthocopoides occupied a 25 mile diameter range in the Helderberg Plateau of Albany County, New York, in 1969. It is the first species of the nominate subgenus to occur in the Western Hemisphere. The bee is described and distinguished from other American Hoplitis, and Hurd and Michener's key to the American subgenera and Mitchell's key to the Eastern species of Hoplitis are modified to include $H$. anthocopoides. The mason bee builds exposed mortar-and-pebble nests on surfaces of rocks and visits only the introduced weed Echium vulgare for pollen and nectar.

\section{Acknowledgments}

I am grateful to the Edmund Niles Huyck Preserve of Rensselaerville, New York, which awarded a summer research fellowship to my wife and myself and provided the facilities which made this study possible. I thank Dr. Eduard Staněk of Uhersky Brod, Czechoslovakia, for providing an unpublished description of $H$. anthocopoides and many helpful comments, and for comparing New York specimens with European ones. The Cornell University insect collection provided European specimens of "Osmia caementaria" that first enabled me to identify the bee. I thank Dr. LaVerne L. 
Pechuman and Dr. John G. Franclemont of Cornell University for critically reading the manuscript. Finally, I express my appreciation to my wife, Kathleen, who aided in collecting the bees, provided constant encouragement, and offered suggestions on the manuscript.

\section{LITERATURE CITED}

Blüthgen, $P$.

1930. Osmia Latr. pp. 808-822 in Schmiedeknecht, O., Die Hymenopteren Nord- und Mitteleuropas. ed. 2. Gustav Fischer, Jena, 1062 pp.

Dalla Torre, C. G. DE

1896. Catalogus Hymenopterorum. vol. 10: Apidae (Anthophila). Engelmann, Liepzig, $643 \mathrm{pp}$.

FrIESE, $\mathrm{H}$.

1923. Die europäischen Bienen (Apidae). Walter de Gruyter \& Co., Berlin, 456 pp. \& 33 pls.

1926. Die Bienen, Wespen, Grab- und Goldwespen. Vol. 1 pt. 1 of Schröder, C., ed., Die Insekten Mitteleuropas, insbesondere Deutschlands. Stuttgart, $192 \mathrm{pp}$.

Gerstaecker, A.

1869. Beiträge zur näheren Kenntniss einiger Bienen-Gattungen. Stettiner Entomol. Zeitung, 30: 315-367.

HEDICKE, H.

1930. Hautflügler, Hymenoptera. Vol. 5 pt. 2 of Brohmer, P., P. Ehrmann, G. Ulmer, eds., Die Tierwelt Mitteleuropas. Quelle \& Meyer, Liepzig, 246 pp.

HURD, P. D., JR.

1954. Distributional notes on Eutricharea, a Palearctic subgenus of Megachile, which has become established in the United States (Hymenoptera: Megachilidae). Entomol. News, 65: 93-95.

Hurd, P. D., JR., and C. D. Michener

1955. The megachiline bees of California (Hymenoptera: Megachilidae). Bull. California Insect Surv., 3: 1-247.

JAYCox, E. R.

1967. An adventive Anthidium in New York State (Hymenoptera: Megachilidae). J. Kansas Entomol. Soc., 40: 124-126.

JøKER, A.

1942. Iagttagelser af Osmia caementarias Redebygningsforhold. Entomol. Meddelelser, 22: 210-214.

Linsley, E. G., and J. W. MacSwain

1943. Observations on the life history of Trichodes ornatus (Coleoptera, Cleridae), a larval predator in the nests of bees and wasps. Ann. Entomol. Soc. Amer., 36: 589-601.

Michener, C. D.

1947. A revision of the American species of Hoplitis (Hymenoptera, Megachilidae). Bull. Amer. Mus. Natur. Histor., 89: 257-317. 
1968. Nests of some African megachilid bees, with description of a new Hoplitis (Hymenoptera, Apoidea). J. Entomol. Soc. South Africa, 31: 337-359.

Michener, C. D. and R. R. Sokal

1957. A quantitative approach to a problem in classification. Evolution, 11: 130-162.

Mitchell, T. B.

1962. Bees of the Eastern United States. Vol. II. North Carolina Agr. Exp. Sta., Tech. Bull. no. 152: 557 pp.

Pechuman, L. L.

1967. Observations on the behavior of the bee Anthidium manicatum (L.). J. New York Entomol. Soc., 75: 68-73.

SCHMIEDEKNECHT, H. L. O.

1884-85. Apidae Europaeae (Die Bienen Europa's). Vol. II, Genus Osmia Panz. R. Friedländer \& Sons, Berlin, 205 pp.

Stephen, W. P., G. E. Bohart, and P. F. Torchio

1969. The Biology and External Morphology of Bees. Agr. Exp. Sta., Oregon State Univ., Corvallis, 140 pp.

Stephen, W. P., and P. F. Torchio

1961. Biological notes on the leaf-cutter bee, Megachile (Eutricharaea)

TORKA, V. rotundata (Fabricius). Pan-Pacific Entomol., 37: 85-93.

1913. Die Bienen der Provinz Posen. Z. naturwiss. Vereins, Deut. Ges. Kunst Wiss., Posen, 20: 97-181. 

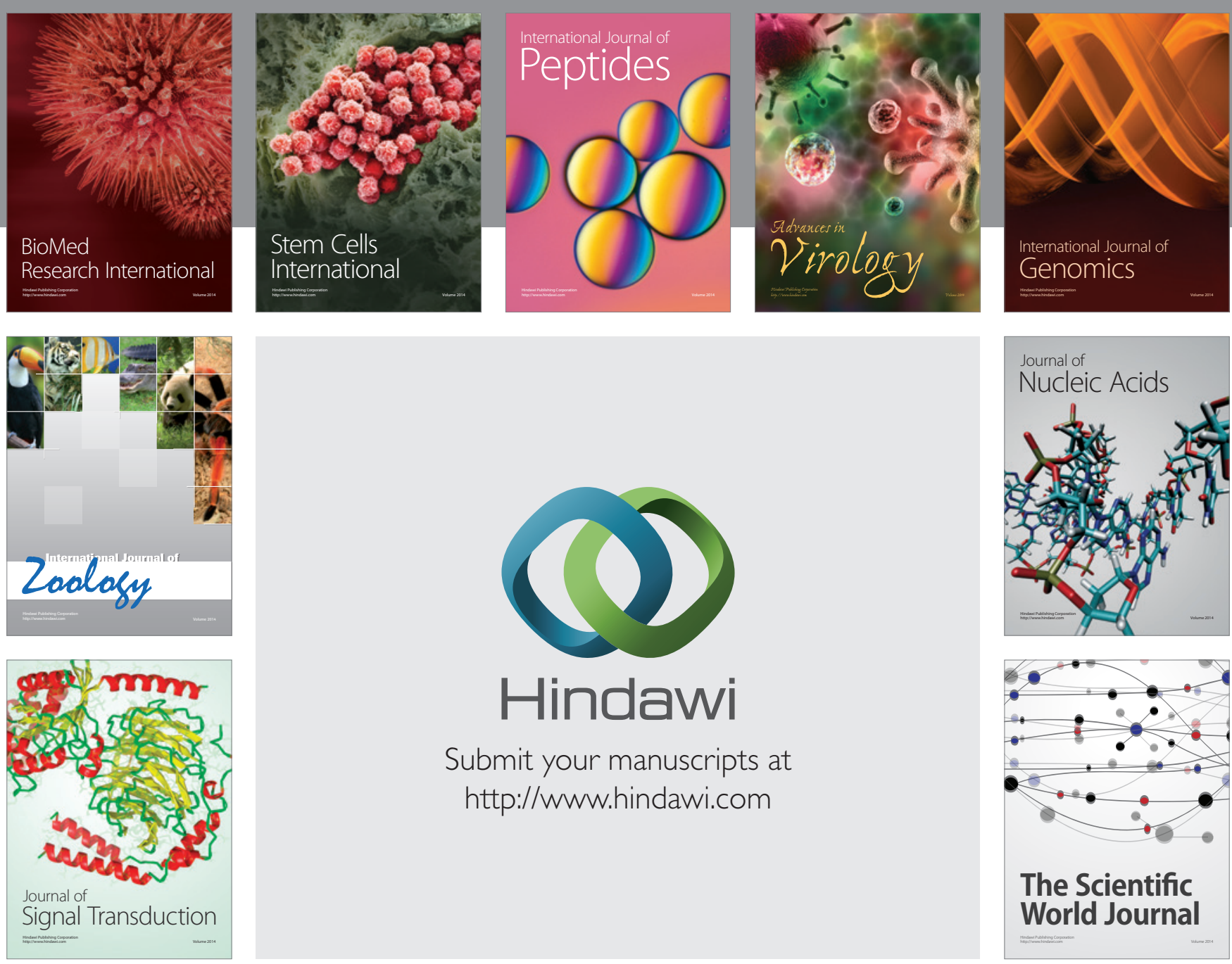

Submit your manuscripts at

http://www.hindawi.com
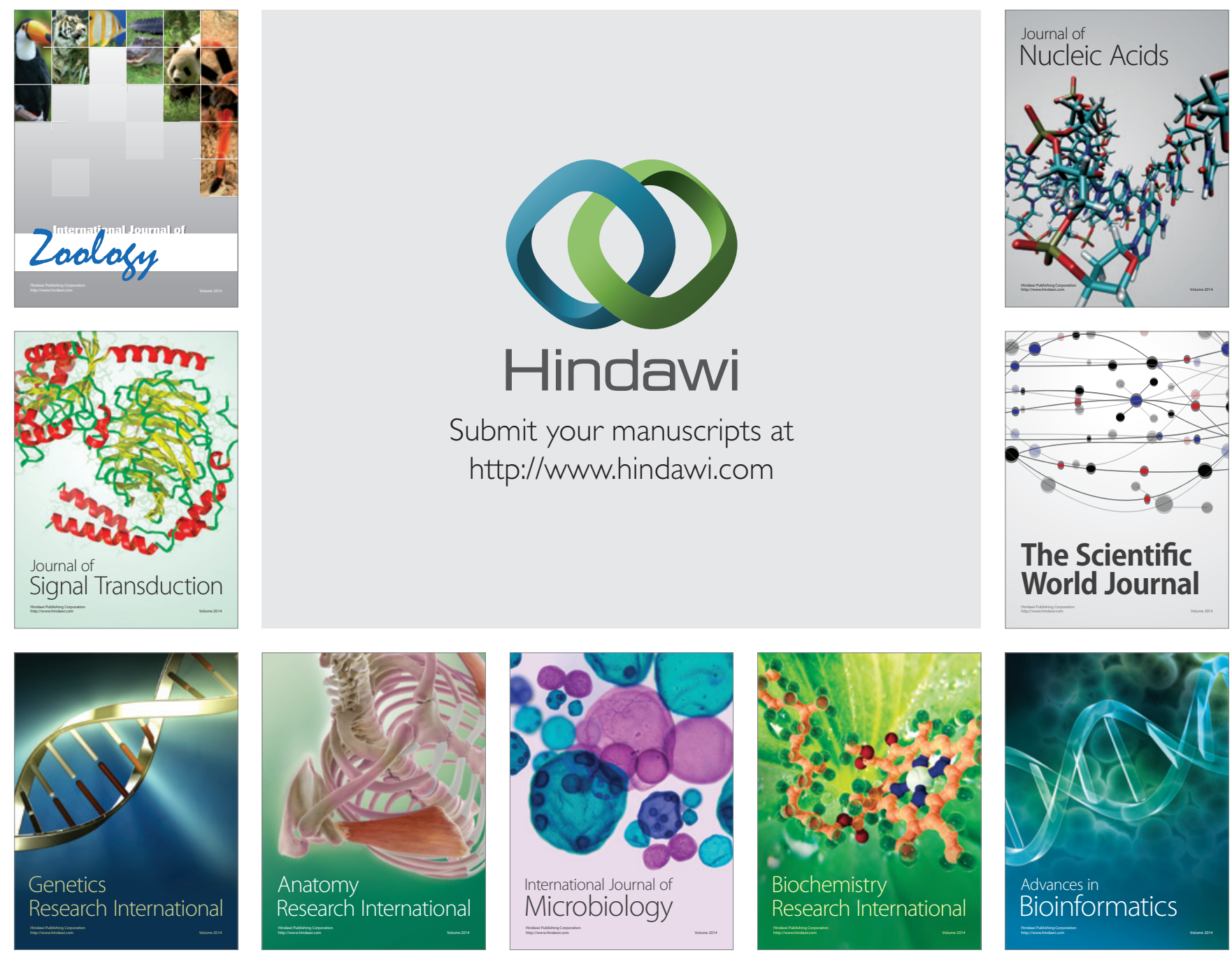

The Scientific World Journal
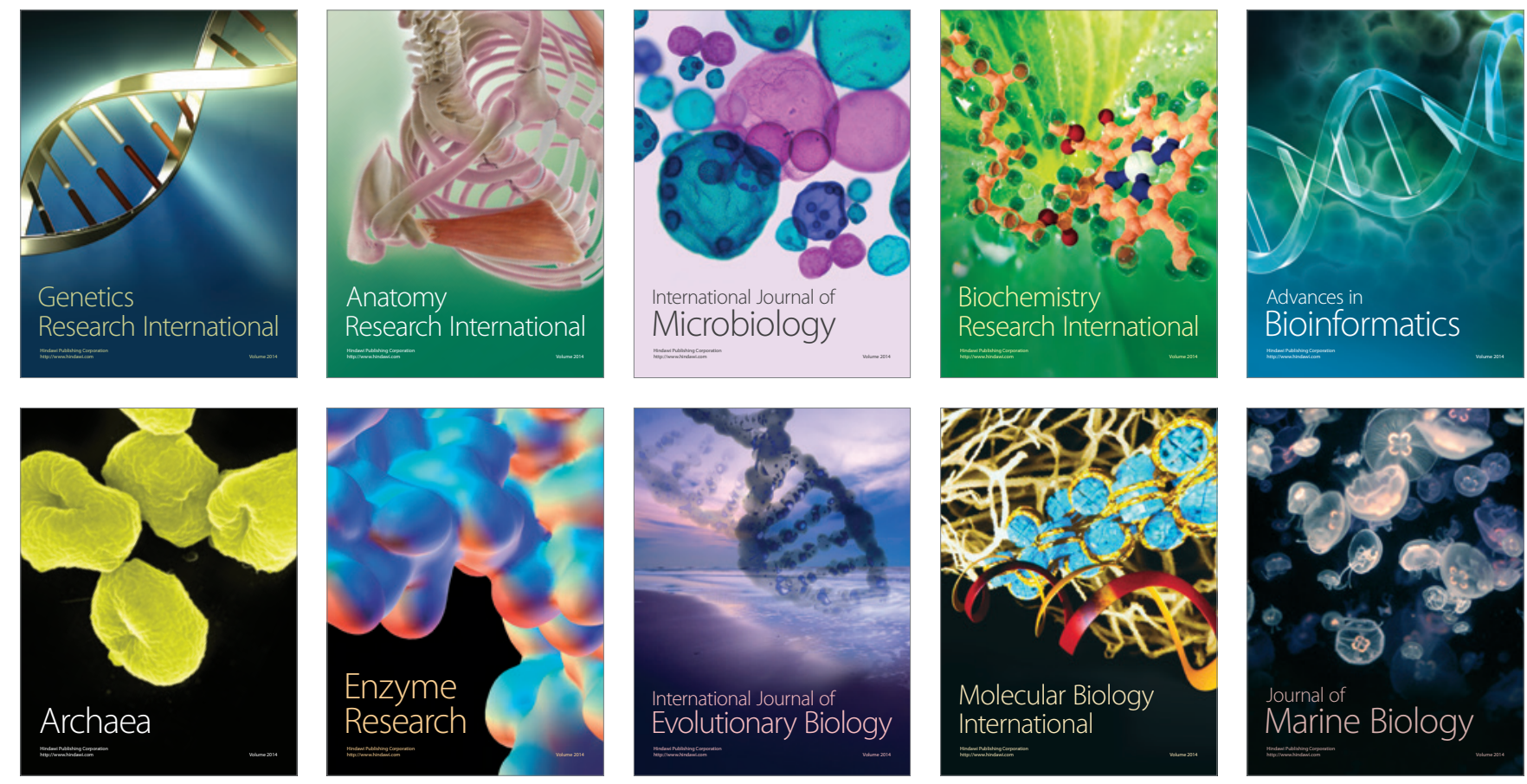